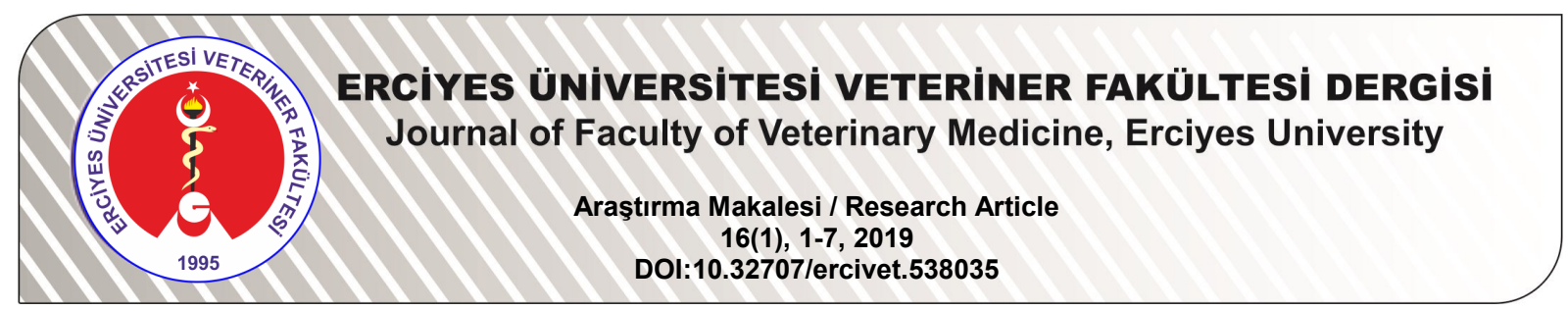

\title{
Effect of Detomidine-Butorphanol-Ketamine and Atipamezole on Clinical, Cardiorespiratory, Haematological Parameters in Sheep
}

\section{Gültekin ATALAN ${ }^{1}$, Güneri ATALAN² Vehbi GUNEŞ ${ }^{3}$, Zafer OKUMUS ${ }^{4}$, Hanifi EROL ${ }^{1}$, Fikret CELEBI ${ }^{5}$, Ali Cesur ONMAZ ${ }^{3}$}

\author{
${ }^{1}$ Erciyes University, Faculty of Veterinary Medicine, Department of Veterinary Surgery, Kayseri-TURKEY \\ ${ }^{2}$ Medical Park Hospital, Department of Anaesthesiology, Elazığ-TURKEY \\ ${ }^{3}$ Erciyes University, Faculty of Veterinary Medicine, Department of Veterinary Internal Medicine, Kayseri-TURKEY \\ ${ }_{4}^{4}$ Atatürk University, Faculty of Veterinary Medicine, Department of Veterinary Surgery,Erzurum-TURKEY \\ ${ }^{5}$ Atatürk University, Faculty of Veterinary Medicine, Department of Physiology, Erzurum-TURKEY
}

*Corresponding author: Gültekin ATALAN; E-mail: gulty@hotmail.com; ORCID: 0000-0002-2613-5638

How to cite: Atalan G, Atalan G, Günes V, Okumus Z, Erol H, Çelebi F, Onmaz AC. Effect of detomidine butorphanolketamine and atipamezole on clinical, cardiorespiratory, haematological parameters in sheep. Erciyes Üniv Vet Fak Derg 2019; 16(1): 1-7.

Summary: The aim of this study was to evaluate the sedative-anesthetic effects of detomidine (D) $30 \mu \mathrm{g} / \mathrm{kg}$, intramuscular (IM), butorphanol (B) $0.2 \mathrm{mg} / \mathrm{kg} \mathrm{IM}$ and ketamine (K) $5 \mathrm{mg} / \mathrm{kg}$, IM combination in sheep. Five female and nine male healthy (1-2 years old) Akkaraman sheep were used as animal material. Detomidine and butorphanol were used to produce sedation. Ten minutes later $\mathrm{K}$ was administrated for anaesthesia. The anaesthetic effect of the drugs was reserved by atipamezole (AT) $30 \mu \mathrm{g} / \mathrm{kg}$, IM administration at 30 minutes after $\mathrm{K}$ injection. The sedative effects of DB demerged in 3 minutes after injection and anaesthetic effects (by the lack of pain stimuli) were visible in 5 minutes after $\mathrm{K}$ injection. Heart rate, body temperature and amplitude $\mathrm{P}$ values significantly decreased until the administration of AT. Contrarily, respiratory rate, PR interval and $\mathrm{R}$ amplitude values increased during anesthesia. Partial venous oxygen pressure $\left(\mathrm{PO}_{2}\right)$ and Partial venous carbon dioxide pressure $\left(\mathrm{PCO}_{2}\right)$ values decreased during anaesthesia. There were no significant alterations seen for hematological parameters including hemoglobin $(\mathrm{Hg})$, white blood cell (WBC), red blood cell (RBC) and hematocrit $(\mathrm{Ht})$ values in sheep. As a result, BDK anaesthetic combination depresses the cardiorespiratoric system but produces adequate sedation and anaesthesia for sheep. AT can be safely used for this anaesthetic combination in sheep.

Key words: Butorphanol, detomidine, ketamine, sheep

\section{Koyunlarda Detomidin-Butarfanol-Ketamin ve Atipamezol'ün Klinik, Kardiyorespiratorik, Hematolojik} Parametreler Üzerine Etkileri

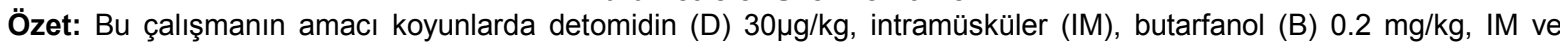
ketamin (K) $5 \mathrm{mg} / \mathrm{kg}$, IM kombinasyonunun sedatif-anestezik etkilerinin değerlendirilmesidir. Beş dişi ve dokuz erkek (1 -2 yaşı) Akkaraman koyunu çalışma materyali olarak kullanıldı. Detomidin ve butarfanolün sedasyon için enjeksiyonundan 10 dakika sonra ketamin anestezi amacı ile uygulandı. Uygulanan anesteziden 30 dakika sonunda atipamezol (AT) $30 \mu \mathrm{g} / \mathrm{kg}$ IM uygulanarak kullanılan anaestezik ilaçların etkileri takip edildi. DB'ün sedatif etkisi enjeksiyonu takiben üç dakika sonra ve anestezik etki (ağrı uyaranlarına tepki kaybı) K enjeksiyonundan beş dakika sonra görüldü. Kalp atımı, vücut ısıSı ve P amplitüt değerlerinde AT enjesinonu kadar önemli değişimler tespit edildi. Solunum sayısının aksine $P R$ aralığı ve $R$ amplitütleri anestezi sürecince azalma gösterdi. Parsiyel venöz oksijen basıncı $\left(\mathrm{PO}_{2}\right)$ ve parsiyel venöz karbondioksit basıncı $\left(\mathrm{PCO}_{2}\right)$ değerleri anestezi süresince azalış gösterdi. Hemoglobin $(\mathrm{Hg})$, lökosit (WBC), eritrosit (RBC) ve hematokrit $(\mathrm{Ht})$ değerlerini içeren hematolojik parametrelerde önemli değişim görülmedi. Sonuç olarak, BDK anestezi kombinasyonunun kardiyorespiratorik sistemi baskıladığı fakat koyunlar için yeterli derecede sedasyon ve anestezi sağladığı görüldü. AT’ün koyunlarda bu anestezi kombinasyonu için güvenli bir şekilde kullanılabileceği tespit edildi.

Anahtar kelimeler: Butarfanol, detomidin, ketamine, koyun

\section{Introduction}

Different alpha-2 adrenoreceptor agonists (xylazine, detomidine, medetomidine, romifidine) are used for sedation and anaesthesia in animals. They have analgesic, sedative and muscle relaxion properties

Geliş Tarihi/Submission Date : 20.02.2018 Kabul Tarihi/Accepted Date $\quad: 26.02 .2018$
$(7,13)$. The use of ideal anaesthetic to reduce pain and limit suffering in animals is very important in veterinary practice $(2,12)$.

Detomidine (D) is a selective alpha-2 adrenoreceptor agonist that produces reliable sedation and analgesia (19). It is a potent alpha-2 adrenoreceptor agonist, has approximately 10 times the binding selectivity of 
xylazine for alpha-2 receptors $(3,11)$. It provides light to heavy sedation according to the dose administration. Use of this agent alone provides adequate sedation for premedication prior to general anaesthesia in sheep (8).

Butorphanol (B) is a synthetically opioid agonistantagonist analgesic agent. It has minimal effects on the cardiopulmonary system in sheep (28). It performs its agonistic by inducing kappa receptors and antagonistic effects on mu receptors, which are responsible for opioid-induced respiratory depression (6).

Ketamine $(\mathrm{K})$ is a dissociative anaesthetic which can be used intravenous (IV) or intramuscularly (IM) for induction of general anaesthesia $(7,9)$. Use of $\mathrm{K}$ may result in muscle hypertonus, early and frequent spontaneous movement and convulsions. Therefore, it is usually necessary to administer other anaesthetic agents such as phenothiazine, or alpha-2 adrenoreceptor agonists (xylazine, detomidine or medetomidine) $(2,7,9)$.

Atipamezole (AT) is a selective alpha-2 adrenoceptor antagonist. It has reversible effects on the cardiovasculary system and sedative effects of alpha-2 agonists $(1,26)$.

In sheep various anaesthetic drugs are used alone or in combination for major surgery or prolonged diagnostic procedure including alpha-2 agonists, thiopental, $\mathrm{K}$ and tiletamine-zolazepam. Xylazine, $\mathrm{D}$ and medetomidine provide light to heavy sedation according to the dose rate administrated. Use of these agents alone provides satisfactory sedation for restraint or premedication in sheep $(8,11,12)$. Major surgery and prolonged diagnostic procedure in sheep is best performed under general anaesthesia. But general anaesthesia or heavy sedation can be complicated and life threatening for sheep. Sheep have four stomach configuration and the digestive process can be compromised when these animals are placed in either lateral or dorsal recumbency (8). The most important problem and disadvantage of general anaesthesia in sheep is hypoxaemia $(8,13,15,23)$.

To our knowledge the Detomidine-ButarphanolKetamine (DBK) combination as an anaesthetic mixture has not been established in sheep. Therefore, the aim of the study were investigate the clinical and cardiorespiratory effects of DBK anaesthesia combination and to evaluate the effectiveness of AT to reserve DBK induced anaesthesia in sheep.

\section{Material and Methods}

This study was approved by the Animal Ethics Committee of the University of Kafkas (04/04). Fourteen healthy Akkaraman sheep (5 female and 9 male, 1-2 years old) weighing $50-70 \mathrm{~kg}$ (mean $59 \mathrm{~kg}$ ) were used as an animal material. They were housed in a sheep farm and kept under standard management condition with free access to feed and water. Antiparasitic drug (Albendozole, $10 \mathrm{mg} / \mathrm{kg}$, intraoral, Vet $A$, Turkey) were given two weeks before the study. The animals were kept off feed a day and $12 \mathrm{~h}$ water prior the study. The left side of neck and pectoral regions were shaved and prepared for placement of catheters and electrodes.

Injectable combination of D (Domesedan, $10 \mathrm{mg} / \mathrm{ml}$, Orion Corporation, Orion Pharma, Espoo site Orionintie 1, FIN-02200 Espoo, Finland, $30 \mu \mathrm{g} / \mathrm{kg}$, IM) and B $0.2 \mathrm{mg} / \mathrm{kg}$ (Torbugesic, $10 \mathrm{mg} / \mathrm{ml}$; Forte Dodge Animal Health, Southamtom, UK) were used to produce sedation. The drugs were diluted in $1 \mathrm{ml}$ of $0.9 \% \mathrm{NaCl}$ solution to ease the handling of small volumes and this volume injected by IM. After $10 \mathrm{~min}$, $\mathrm{K} 5 \mathrm{mg} / \mathrm{kg}$ (Ketalar, $50 \mathrm{mg} / \mathrm{kg} \mathrm{ml}$; Eczacıbası, Istanbul, Turkey) was injected by IM. Thirty minutes later AT $30 \mu \mathrm{g} / \mathrm{kg}$ (Antisedan, Farmos Group, Turku, Finland in $1 \mathrm{ml} 0.9 \% \mathrm{NaCl}$ solution, IM) were prepared and injected in all sheep.

The following parameters were measured before and 10 min after pre-medication with $D$ and $B ; 10,20$ and 30 min after injection of $\mathrm{K}$ during anaesthesia, and at 10 min following administration of AT. Heart rate (HR, beats/per $\mathrm{min})$, respiratory rate (RR, breaths/per $\mathrm{min}$ ) electrocardiograms (ECGs) obtained from extremity derivations and body temperature (BT) were measured at the above-mentioned time-intervals. The ECGs were recorded by a direct writing electrocardiograph (Logos 8821; Logos Medical Co. Ltd, Tokyo, Japan). All ECGs were standardized at $1 \mathrm{mV}=10 \mathrm{~mm}$, with chart speed of $50 \mathrm{~mm} / \mathrm{s}$. Leads I, II, III, aVR, aVL, aVF were determined. The duration and amplitude of waves on the trace were measured in lead II.

Ten millilitres of blood samples were collected from the left jugular vein. Hematologic analysis consisted of counting the number of WBC and RBC, packed cell volume (PCV) and measurement of Hg concentration. Venous blood gas analyses were also performed to determine the alterations at the level of $\mathrm{PH}$, $\mathrm{PO}_{2}, \mathrm{HCO}_{3}$ and $\mathrm{PCO}_{2}$ by using Rapidlab 248 (Chiron Diagnostics, USA) device analyser.

The recovery time of the sheep was determined as being when the animal regained all motor and sensory functions and, the time ( $\mathrm{min})$ until the animals spontaneously regained their feet (on-feet), standing and starting walking consciously after anaesthesia. Therefore, the effects of AT were evaluated by recording the time from injection until the animals were on feet, the time elapsing until resedation occurred. Resedation was evaluated in a more subjective manner by observing signs such as reduced alertness, head dropping or recumbency. Resedation was considered to have ended when the sheep became alert, 
Table 1. Evaluation of sedation-anaestheasia quality for sheep anaesthetized by detomidine, butorphanol and ketamine combination and alteration following atipamezole administration

\begin{tabular}{|c|c|c|c|c|c|c|c|}
\hline Sheep no & $0 \mathrm{~min}$ & $\begin{array}{l}\text { Pre } \\
\text { 10. (min) }\end{array}$ & $\begin{array}{l}\text { An } \\
10 .(\min )\end{array}$ & $\begin{array}{l}\text { An } \\
20 .(\min )\end{array}$ & $\begin{array}{l}\text { An } \\
30 .(\min )\end{array}$ & $\begin{array}{l}\text { AT } \\
10 .(\min )\end{array}$ & $\begin{array}{l}\text { Recovery } \\
\text { Time (min) }\end{array}$ \\
\hline 1 & 0 & ++ & ++ & +++ & + & 0 & 10 \\
\hline 2 & 0 & ++ & +++ & +++ & ++ & 0 & 13 \\
\hline 3 & 0 & + & +++ & +++ & + & 0 & 14 \\
\hline 4 & 0 & ++ & +++ & +++ & + & 0 & 10 \\
\hline 5 & 0 & ++ & +++ & +++ & + & 0 & 15 \\
\hline 6 & 0 & + & +++ & +++ & ++ & 0 & 18 \\
\hline 7 & 0 & ++ & +++ & +++ & + & 0 & 21 \\
\hline 8 & 0 & ++ & +++ & +++ & + & 0 & 12 \\
\hline 9 & 0 & + & +++ & +++ & ++ & 0 & 12 \\
\hline 10 & 0 & ++ & ++ & +++ & + & 0 & 10 \\
\hline 11 & 0 & + & +++ & +++ & + & 0 & 14 \\
\hline 12 & 0 & ++ & +++ & +++ & + & 0 & 12 \\
\hline 13 & 0 & ++ & +++ & +++ & ++ & 0 & 13 \\
\hline 14 & 0 & ++ & +++ & +++ & + & 0 & 12 \\
\hline
\end{tabular}

Min: minute, Pre: premedication, An: Anesthesia, 0: baseline value, 0: Normal conscious position. All reflexes available, + : Partly response to needle prick stimuli and hardly responsive to environmental stimuli. Dilated pupilla, availability of palpebral and pedal reflexes responsive to eye and ear stimulus unable to stand up and tend to stay in lateral recumbency, ++: Limited palpebral and pedal reflexes, hardly has foot withdrawal response against needle prick, recumbent and unable to lift their heads (down), +++: No response to any pain reflexes, satisfactory muscle relaxation, deep general anaesthesia, no sign of reflexes.

responding normally on being approached and handled. Motor functions were tested as an apparent response to needle prick to legs and to various areas of abdominal area, a complete ability of hold its head in normal, resistance of the head and the neck by palpation against pulling and to attempt to from the table. Sensory functions were examined as response palpebral and corneal reflexes and as respond to sound.

The sedative and anesthetic effects of the drugs were assessed according to following criteria. Muscle relaxation was defined as the condition of no pedal reflex and head control.

Data were statistically evaluated by means of descriptive statistics and repeated measure ANOVA with the Bonferroni correction for multiple comparisons using MINITAB statistical program (Version 12.0 Minitab Inc., State College, PA, USA). Data are presented as Mean \pm Std.Error. Measurements were compared with baseline values (time $=0$ )

\section{Results}

The sedative and anaesthetic effects after drug administration are summarized in Table 1 . The DBK drug combination used produced a satisfactory sedation and anaesthesia for the all sheep. The sedative effect of the DB appeared within 3 minutes and the anaesthetic effect started within 5 to 8 minutes after $\mathrm{K}$ administration as indicated by lack of pain stimuli and no reflexes. Profound anaesthesia was determined between 10 and 20 min after $\mathrm{K}$ administration but decreased at $30 \mathrm{~min}$. All sheep recovered successfully.
The injection of AT effectively reversed the sedative effects of $D$, with the sheep regaining their feet after $4.8 \mathrm{~min}$. All animals showed excitement after the injection of the antagonist, the animals being over-alert, nervous and exhibiting muscle tremor. No relapse into sedation was observed. The effect of AT on recovery was observed within 2 to 6 min (mean 4.8 min) after AT administration. There were full responses for motoric and sensoric functions at 10 min after AT injection.

Alterations in HR, RR and BT are summarized in Table 2. Mean heart rate decreased after premedication until the administration of AT $(P<0.05)$, but increased following the AT injection. RR increased throughout the anaesthesia and after AT injection. There were no statistically differences seen between $\mathrm{RR}$ values during anaesthesia. Body temperature declined significantly $(P<0.05)$ gradually throughout the anaesthesia from 39.5 to 38.7 , which was still low $10 \mathrm{~min}$ after AT injection.

ECG values are summarized in Table 3. Amplitude of $P$ values decreased at 30 minutes after $K$ anaesthesia but returned its baseline value after $10 \mathrm{~min}$ of AT injection. $P R$ value and $R$ amplitude increased gradually during anaesthesia but decreased after the administration of AT. Q-T value gradually increased at 10 min after $\mathrm{DB}$, at 10,20 after $\mathrm{K}$ administration $(P<0.05)$ and having the highest value at 30 minute of anaesthesia and, the increasing was significant after 10 min of AT injection. T amplitude increased significantly at 10 min after DB injection $(P<0.05)$. But returned to approximate values of baseline during the anaesthesia. 
Table 2. Mean heart and respiratory rates and body temperature (mean $\pm S E$ ) for fourteen sheep anaesthetized with detomidine $(30 \mu \mathrm{g} / \mathrm{kg})$ butorpanol $(0.2 \mathrm{mg} / \mathrm{kg})$ and ketamine $(5 \mathrm{mg} / \mathrm{kg})$ combinations and reversal by atipamezole $(30 \mu \mathrm{g} / \mathrm{kg})$

\begin{tabular}{lllll}
\hline Parameters & Time $($ Min $)$ & HR $($ beats $/$ min) & RR (beats/min) & BT $\left(C^{\circ}\right)$ \\
\hline Baseline value & 0 & $94.11 \pm 2.13$ & $39.78 \pm 2.79$ & $39.53 \pm 0.09$ \\
Premedication & 10 & $60.22 \pm 4.71^{*}$ & $50.67 \pm 7.18$ & $39.29 \pm 0.09$ \\
Anaesthesia & 10 & $64.44 \pm 4.24^{*}$ & $50.0 \pm 7.22$ & $38.96 \pm 0.06^{*}$ \\
& 20 & $68.22 \pm 2.67^{*}$ & $42.89 \pm 4.51$ & $38.91 \pm 0.16^{*}$ \\
Post-atipamezole & 10 & $66.00 \pm 2.0^{*}$ & $41.11 \pm 3.45$ & $38.71 \pm 0.17^{*}$ \\
\hline
\end{tabular}

: Significantly $(P<0.05)$ different

The blood gas and haemodynamic parameters are summarized in Table 4. $\mathrm{pH}$ value decreased slightly at 10 min after $\mathrm{DB}$ and $\mathrm{K}$ injection but was not significant. $\mathrm{PCO}_{2}$ value increased significantly after $\mathrm{DB}$ and $\mathrm{K}$ injection during the anaesthesia but turned to decrease after AT administration. $\mathrm{PO}_{2}$ value decreased significantly during the anaesthesia but was increased at $10 \mathrm{~min}$ after AT injection. The values of $\mathrm{HCO}_{3}, \mathrm{CtCO}_{2}$ and $\mathrm{PCO}_{2}$ increased significantly during anaesthesia and even after AT injection. There were no significant differences for $\mathrm{Hg}, \mathrm{WBC}$, RBC, $\mathrm{PVC}$ and $\mathrm{Ht}$ values compared to their baseline values

Table 3. Alterations in ecocardiographic parameters(mean $\pm S E)$ for fourteen sheep anaesthetised with detomidine, butorphanol and ketamine combinaiton and reversed by atipamezole injection

\begin{tabular}{llllllllll}
\hline Parameters & $\begin{array}{l}\text { Time } \\
\text { (Min) }\end{array}$ & P-time & $\begin{array}{l}\text { P ampli- } \\
\text { tude }\end{array}$ & $\begin{array}{l}\text { PR inter- } \\
\text { val }\end{array}$ & $\begin{array}{l}\text { QRS } \\
\text { time }\end{array}$ & $\begin{array}{l}\text { R ampli- } \\
\text { tude }\end{array}$ & $\begin{array}{l}\text { QT ampli- } \\
\text { tude }\end{array}$ & $\begin{array}{l}\text { Tampli- } \\
\text { tude }\end{array}$ & $\begin{array}{l}\text { ST } \\
\text { time }\end{array}$ \\
\hline Baseline & 0 & 0.03 & 0.04 & 0.08 & 0.04 & 0.16 & 0.22 & 0.20 & 0.18 \\
value & & \pm 0.004 & \pm 0.006 & \pm 0.004 & \pm 0.00 & \pm 0.030 & \pm 0.005 & \pm 0.058 & \pm 0.010 \\
Premedica- & 10 & 0.03 & 0.05 & 0.14 & 0.06 & 0.24 & 0.26 & 0.40 & 0.20 \\
tion & & \pm 0.004 & \pm 0.008 & $\pm 0.004^{*}$ & \pm 0.004 & \pm 0.007 & $\pm 0.005^{*}$ & \pm 0.079 & \pm 0.006 \\
Anaesthesia & 10 & 0.03 & 0.05 & 0.14 & 0.05 & 0.24 & 0.26 & 0.32 & 0.21 \\
& & \pm 0.005 & \pm 0.009 & $\pm 0.006^{*}$ & \pm 0.006 & \pm 0.007 & $\pm 0.005^{*}$ & \pm 0.011 & \pm 0.003 \\
& 20 & 0.03 & 0.03 & 0.14 & 0.06 & 0.26 & 0.28 & 0.40 & 0.23 \\
& & \pm 0.005 & \pm 0.004 & $\pm 0.007^{*}$ & $\pm 0.006^{*}$ & \pm 0.015 & $\pm 0.008^{*}$ & \pm 0.012 & $\pm 0.003^{*}$ \\
& 30 & 0.02 & 0.01 & 0.13 & 0.05 & 0.22 & 0.30 & 0.26 & 0.27 \\
Post-At & 10 & \pm 0.004 & $\pm 0.003^{*}$ & $\pm 0.001^{*}$ & \pm 0.003 & \pm 0.012 & $\pm 0.008^{*}$ & \pm 0.037 & $\pm 0.003^{*}$ \\
& & 0.03 & 0.04 & 0.12 & 0.05 & 0.18 & 0.27 & 0.22 & 0.21 \\
& & \pm 0.004 & \pm 0.01 & $\pm 0.005^{*}$ & \pm 0.003 & \pm 0.022 & $\pm 0.005^{*}$ & $\pm 0.072^{*}$ & \pm 0.004 \\
\hline
\end{tabular}

*: Significantly $(P<0.05)$ different.

Table 4. Alterations in blood gase and heametalogic parameters (mean $\pm S E)$ for fourteen sheep anaesthetised with detomidine, butorphanol and ketamine combinaiton and reversed by atipamezole injection

\begin{tabular}{llllllllllll}
\hline $\begin{array}{l}\text { Parame- } \\
\text { ters }\end{array}$ & $\begin{array}{l}\mathrm{T} \text { (Mime } \\
\text { (Min) }\end{array}$ & $\mathrm{pH}$ & $\mathrm{PCO}_{2}$ & $\mathrm{PO}_{2}$ & $\begin{array}{l}\mathrm{HCO}_{3} \\
\text { act }\end{array}$ & $\begin{array}{l}\mathrm{BE} \\
(\mathrm{ecf})\end{array}$ & $\mathrm{ctCO}_{2}$ & $\mathrm{Hg}$ & $\mathrm{WBC}$ & $\mathrm{RBC}$ & $\mathrm{PCV}$ \\
\hline Baseline & 0 & 7.40 & 34.9 & 44.6 & 20.0 & -4.31 & 20.9 & 9.4 & 7.67 & 11542 & 30.56 \\
value & & \pm 0.08 & \pm 1.18 & \pm 1.19 & \pm 0.45 & \pm 0.31 & \pm 0.54 & \pm 0.12 & \pm 0.81 & \pm 855.29 & \pm 0.33 \\
Premedica- & 10 & 7.39 & 39.5 & 31.8 & 22.4 & -1.88 & 23.6 & 8.3 & 8.81 & 11133 & 31.33 \\
tion & & \pm 0.08 & $\pm 1.05^{*}$ & $\pm 1.51^{*}$ & $\pm 0.34^{*}$ & $\pm 0.31^{*}$ & $\pm 0.36^{*}$ & $\pm 0.16^{*}$ & \pm 0.67 & \pm 138.69 & \pm 0.37 \\
Anaesthe- & 10 & 7.36 & 42.6 & 32.1 & 22.9 & -1.79 & 23.8 & 8.7 & 12.51 & 10611 & 30.89 \\
sia & & \pm 0.07 & $\pm 1.32^{*}$ & $\pm 1.96^{*}$ & \pm 0.58 & \pm 0.59 & \pm 0.66 & $\pm 0.14^{*}$ & $\pm 0.29^{*}$ & \pm 139.63 & \pm 0.92 \\
& 20 & 7.40 & 39.1 & 35.7 & 23.3 & -1.37 & 24.0 & 9.4 & 6.44 & 13011 & 30.33 \\
& & \pm 0.07 & \pm 1.37 & $\pm 2.40^{*}$ & \pm 0.70 & \pm 0.74 & \pm 0.81 & \pm 0.01 & \pm 0.17 & $\pm 484.50^{*}$ & \pm 0.33 \\
& \multirow{2}{*}{30} & 7.40 & 40.3 & 37.5 & 24.2 & 0.58 & 25.7 & 9.5 & 10.83 & 12550 & 30.33 \\
& & \pm 0.01 & $\pm 0.93^{*}$ & \pm 1.91 & $\pm 0.60^{*}$ & $\pm 0.85^{*}$ & $\pm 0.78^{*}$ & \pm 0.10 & \pm 0.91 & $\pm 529.74^{*}$ & \pm 0.33 \\
Post-At & 10 & 7.40 & 37.6 & 39.9 & 22.9 & -0.90 & 23.6 & 9.3 & 9.2 & 11991 & 30.22 \\
& & \pm 0.01 & \pm 1.45 & \pm 1.52 & $\pm 0.78^{*}$ & \pm 1.00 & \pm 1.01 & \pm 0.53 & \pm 0.93 & \pm 996.02 & \pm 0.22 \\
\hline
\end{tabular}

*: Significantly $(P<0.05)$ different 
in spite of some degree of alterations between the anaesthesia intervals.

\section{Discussion and Conclusion}

After premedication partly reflex $(+)$ in four sheep, limited reflex (++) in 10 sheep were recorded. At 10 , 20.minutes of anaesthesia deep general anaesthesia was seen in all sheep. At 30.minute of anaesthesia partly reflex (+) in 10 sheep, limited reflex (++) in 4 sheep were recorded. From these, DBK anaesthetic combination can be used ideally in short-term anaesthesia for sheep. There was a smooth muscle tone for operative intervention $(6,11,14)$.

A decrease in HR was recorded for all sheep during anaesthesia following administration of $D$ which was significant at 10 min measurement. The bradycardic effects of alpha-2 agonist attributed to decreased sympathetic outflow from CNS, decreased catecholamine release in heart and increased vagal activity, which is a characteristic response to alpha-2 agonist $(4,27)$. Decreasing in HR value consisted significantly after injection of $\mathrm{K}$ but was higher compared to the values determined at $10 \mathrm{~min}$ after premedication. Ketamine is a cardio stimulatory agent in sheep. This effect of $\mathrm{K}$ induces cardiovasculary alteration by stimulating catecholamines due to depression of baroreceptors. After that catecholamines direct effects CNS (10). In this study D and K injection to sheep at a dose concentration of $30 \mu \mathrm{g} / \mathrm{kg}, 5 \mathrm{mg} / \mathrm{kg}$ resulted in a decreased HR value which was attributed to the depression effects on catecholamine releasing.

The tachycardia reported after $\mathrm{K}$ appears to be related to direct CNS stimulation causing a combination of sympathomimetic and parasympatholytic effect (24). In our study, there was no tachycardiac effect after $\mathrm{K}$ administration; this was attributed to the significant effect of $D$.

A mean of $1.6^{\circ} \mathrm{C}$ decrease in body temperature was noted during the present study even after the decrease was significant at 10 min following AT injection. This is abolishing of body temperature during the general anaesthesia. Decreasing in body temperature should be taken into consideration particularly for the long duration of anaesthesia. Furthermore, heat loss may also be promoted by heat exchange with the environment. Khan et al. (14) compared to sedative and analgesic effects of xylazine and detomidine in small ruminants and found a decrease for HR and BT values during anaesthesia.

A significant increase in RR occurred immediately after $\mathrm{D}$ and $\mathrm{K}$ injection but started to decrease to the later stage of anaesthesia in the present study. It has been reported previously in the sheep that butorphanol alone does not produce significant cardiopulmonary effects at the dosage of $0.5 \mathrm{mg} / \mathrm{kg}(21)$.
Respiratory rate decreased when $\mathrm{K}$ was administered in sheep (25) but in our study RR increased unlike the quoted study. $D$ induced hypoxemia and the resultant tachypnea in sheep has been well documented (8). It is believed that this is due to alpha-2 adrenoreceptor mediated contraction of the airway or a reduction in pulmonary blood flow $(16,20)$. However, absence of any change in RR after $\mathrm{D}, \mathrm{B}$ and $\mathrm{K}$ administration at 10 min of anaesthesia suggests that $D$ and $B$ induced hypoxemia and subsequent tachypnea might have played a role in the increase in RR during DBK anaesthesia in our study. Moreover, a transient increase in respiratory rate was accompanied by a sustained increase in $\mathrm{PCO}_{2}$. However, 10 min of anaesthesia $\mathrm{PCO}_{2}$ decrased and $\mathrm{PH}$ and $\mathrm{PO}_{2}$ values increased depending on RR. Interestingly, sheep anesthetized with DBK had a significantly lower $\mathrm{PO}_{2}$ than sheep anesthetized with propofol (17). Several studies have indicated that hypoxemia is a characteristic response to the administration of an alpha-2 adrenoceptor mediated, because it could be prevented or reversed by alpha-2 antagonist.

There were no significant structural alterations in ECG parameters, but some parameters changed compared to baseline value. ECG parameters particularly returned to baseline values after AT administration. The alterations were particularly detected at $P$ amplitude. Decreasing in $\mathrm{P}$ amplitude due to anaesthesia is an indicator of declining in atrial activation. Therefore, anaesthetic agents have effects on atrial stimulation. Transmission time in AV node increased due to anaesthesia but PR intervals extended, which might be commented a temporary 1 . degree of $A V$ bloc. Horse subjected to detomidine injection had II degree of AV block (5). Differences obtained from this study might be due to dose of drugs and different animal species. Increase in QRS time after $10 \mathrm{~min}$ and promotion in $\mathrm{R}$ amplitude after 20 min was considered to be due to a decrease in ventricular depolarization.

Recently the alpha-2 adrenoceptor antagonist (Atipamezole, yohimbine, talozoline) are widely used in veterinary practice. Atipamezole effectively antogised the depressant effect of alpha-2 agonists $(1,5,18)$. In this study following AT injection at $10 \mathrm{~min}$ $H R$ and $R R$ values significantly increased. A decrease in $\mathrm{PCO}_{2}$ and increase in $\mathrm{PO}_{2}$ values also supported the effect of AT. AT reduced the elimination half-life of D in sheep (6). Similar effect of AT have also been reported in dogs, $30 \mathrm{~min}$ after $\mathrm{D}$ resulting in an increased clearance of $D$ (23). The effect of AT was rapid and persistent. No relapse into sedation was observed, in contrast to the resedation observed previously in reinder and dairy calves (8).

The blood gas analysis is the standart method for obtaining the alteration of blood values during anaesthesia (22). In the current study the significant alte- 
rations were recorded for $\mathrm{PCO}_{2}, \mathrm{PO}_{2}, \mathrm{HCO}_{3}, \mathrm{BE}$ (ecf) and $\mathrm{CtCO}_{2}$ values during anaesthesia. The increase of $\mathrm{PCO}_{2}$ attribute to decreasing in $\mathrm{PH}$ and $\mathrm{BE}$ (ecf) values. The decrease in $B E$ (ecf) value indicates the accompanying of a mild metabolic acidosis (16). At the same time $\mathrm{HCO}_{3}, \mathrm{BE}(\mathrm{ecf})$ and $\mathrm{CtCO}_{2}$ values increased. $\mathrm{PH}$ value decreased at $10 \mathrm{~min}$ but there was no statistically difference recorded. The alteration of $\mathrm{PCO}_{2}$ increased $\mathrm{BE}$ (ecf), $\mathrm{HCO}_{3}$ and $\mathrm{CtCO}_{2}$ values. Decreased cardiac output, hypotension and inadequate tissue perfusion caused by the cardiovasculary depression may cause metabolic acidosis (2). The alteration in blood gas parameters, values of WBC, $\mathrm{RBC}, \mathrm{Hg}, \mathrm{PVC}$ and clinical findings related effects of anaesthetic agents. At the same time using of anaesthetic agents can cause respiratory acidosis (10). Therefore increase of $\mathrm{PCO}_{2}$, decrease of $\mathrm{PO}_{2}$ and $\mathrm{pH}$ values after premedication and $10 \mathrm{~min}$ of anaesthesia supported a mild metabolic acidosis in the present study.

The antagonistic effects of atipamezole on D induced sedation have been reported in sheep previously $(11,14)$. In the present study, the sheeps were awake completely within three to five minutes without any side effects. The effect of AT observed in this study for heart rate was in accordance with those of the study reproted by Galatos (6).

In conclusion, DBK combination produced a profound sedation and anaesthesia in sheep. The combination appeared to be a reliable anaesthesia with no significant adverse side-effects.

\section{References}

1. Atalan G, Uzun M, Demirkan I, Yıldız S, Cenesiz $M$. Effect of medetomidine-butorphanol-ketamine anaesthesia and atipamezole on heart and respiratory rate and cloacal tempature of domestic pigeons. J Vet Med A Physiol Pathol Clin Med 2002; 49(6): 281-5.

2. Aantaa R. Alpha-2 adrenoceptor antagonists. Baillieres Clim Anaesthesiol 2000; 14: 285-92.

3. Chittick E, Horne W, Wolfe B, Sladky K, Loomis M. Cadiopulmonary assessment of medetomidine, ketamine, and butorphanol anaesthesia in Captive Thomson's Gazelles (Gazella Thomsoni). J Zoo Wildl Med 2001; 32(2): 168-75.

4. Dart CM. Advantages and disadvantage of using alpha-2 agonists in veterinary practice. Aust Vet J 1999; 77(11): 720-2.

5. DiMaioKnych HK, Covamubias V, Steffey EP. Effect of yohimbine on detomidine induced changes in behavior, cardiac and blood parameters in the horse. Vet Anaesth Analg 2012; 39(6): 574-83.
6. Galotos AD. Anaesthesia and analgesia in sheep and goats. Vet Clin Food Anim 2001; 27:47-59.

7. Hall LW, Clerk KW. Anaesthesia in dog. Hall LW, Clerk KW eds. In: Veterinary Anaesthesia. Philadelphia: Bailliere Tindall,1991, pp. 51-347.

8. Hall LW, Clerk KW, Trim CM. Anaesthesia of sheep, goats and other herbivores. Hall LW, Clerk $\mathrm{KW}$, Trim CM eds. In: Veterinary Anaesthesia. England: W.B. Saunders, 2000, pp. 341-66.

9. Hartsfield SM. Advantages and guidelines for using ketamine for induction of anaesthesia. Vet Clin Small Anim 1992; 22: 266-7.

10. Howard BW, Lagutchik MS, Januszkiewicz AJ, Martin DG. The cardiovascular response of sheep to tiletamine-zolazepam and butorphanol tartrate anaesthesia. Vet Surg 1990; 19(6): 461-7.

11. Kariman A, Sharifi D, Nowrouzian I. Evaluation of detomidine hydrochloride, diazepam and thiopental sodium combination on cardiovascular function and hemodynamics in sheep. Small Rum Res 1998; 29(1): 43-9.

12. Kastner SBR. Alpha2 agonists in sheep: A review. Vet Anaesth Analg 1998; 33(2): 79-96.

13. Kastner SBR, Ohlerth S, Pospischil A, Boller J, Huhtinen MK. Dexmedetomidine induced pulmonary alterations in sheep. Res Vet Sci 2007; 83 (2): $217-26$.

14. Khan MA, Ashraf M, Pervez K, Rashid HB, Mahmood AK, Chaudhry M. Comparative effects of detomidine and xylazine as sedative and analgesic agents in small ruminants. Pak Vet J 2004; 24 (2): $16-20$.

15. Laitinen OM. Clinical observation on medetomidine/ketamine anaesthesia in sheep and its reversal by atipemazole. J Assoc Vet Anaest 1990; 17: 17-19.

16. Lin HC, Wallace SS, Tyler JW, Robbins RL, Thurmon JC, Wolfe DF. Comparasion of tilataminezolazepam-ketamine and tiletamine-zolezapamketamine-xylazine anaesthesia in sheep. Aust Vet J 1994; 71(8): 239-42.

17. Lin HC, Prohit RC, Powe TA. Anaesthesia in sheep with propofol or with xylazine-ketamine followed by Halothane. Vet Anaesth Analg 1997; 26(3): 247-52.

18. Mahmood BM, Mohammad FK. Antagonism of medetomidine sedation in goats by atipamezole and yohimbine. Turk J Vet Anim Sci 2008; 32: 429-32. 
19. Mama KR. Anaesthesic management of Horse: Intravenous Anaesthesia. http://www.ivis.org/ advances/Steffey_Anesthesia/mama_horse/

chapter_frm.asp?LA=1, Acces of date; 16.01.2009.

20. Nolan A, Livingston A, Waterman A. The effects of alpha-2 adrenoceptoragonists on airway pressure in anesthetized sheep. J Vet Pharmacol Therap 1986; 9: 157-63.

21. O'hair KC, Dodd KT, Philips YY, Beattie RJ. Cardiopulmonary effects of nalbuphine Hydrochloride and butorphanol tartrate in sheep. Lab Anim Sci 1988; 38(1): 58-61.

22. Onmaz AC, Gunes V, Atalan G, Gelfert CC, Atalan $\mathrm{G}$. Comparasion of arterial and venous blood gas values in sheep before and during isoflurane anaesthesia. Revue Med Vet 2009; 160: 356-61.

23. Ranheim B, Arnemo JM, Stuen S, Horsberg TE. Medetomidine and atipamezole in sheep: Disposition and clinical effects. J Vet Pharmacol Therap 2000; 23(6): 401-4.

24. Short CE. Effects of anticholinergic treatment on the cardiac and respiratory systems in dogs sedated with medetomidine. Vet Rec 1991; 129(14): 310-13.

25. Thurmon JC, Kumar A, Link EP. Evaluation of ketamine hydrochloride as an anaesthetic sheep. J Am Vet Med Assoc 1973; 162: 293-7.

26. Verstegen J, Petcho A. Medetomidinebutorphanol-midozalam for anaesthesia in dogs and its reversal by atipamezole. Vet Rec 1993; 132(14): 353-7.

27. Waterman AE, Nolan A, Livingston A. Influence of idazoxan on the respiratory blood gas changes induced by alpha2-adrenoceptor agonist drugs in conscious sheep. Vet Rec 1987; 121 (5): 105-7.

28. Waterman AE, Livingston A, Amin A. Analgesic activity and respiratory effects of butorphanol in sheep. Res Vet Sci 1991; 51(1): 19-23. 